\title{
UK Debt Sustainability: Some Nonlinear Evidence and Theoretical Implications
}

\author{
John Considine* \\ Liam A. Gallagher** \\ Current Draft: April 2004 \\ Do Not Cite or Quote
}

\begin{abstract}
This paper assesses whether the UK public finances were sustainable for the period 1919 to 2001 using a nonlinear representation of the debt to GDP ratio and thus provides a more robust test of debt sustainability. Empirical evidence supports debt sustainability. Moreover, the ESTAR representation is evidence that sustainability is the result of active debt management rather than tax-smoothing. The results strongly support the active debt management hypothesis for the UK.
\end{abstract}

JEL Classification: E62, C22

Keywords:

* Department of Economics, University College Cork, Ireland

** Business School, Dublin City University, Glasnevin, Dublin 9, Ireland

Corresponding Author:

Professor Liam Gallagher

Business School

Dublin City University

Glasnevin

Dublin 9

Ireland

Tel: ++ 35317005399

Fax: ++ 35317005446

Email: liam.gallagher@dcu.ie 


\section{UK Debt Sustainability: Some Nonlinear Evidence and Theoretical Implications}

Abstract: This paper assesses whether the UK public finances were sustainable for the period 1919 to 2001 using a nonlinear representation of the debt to GDP ratio and thus provides a more robust test of debt sustainability. Empirical evidence supports debt sustainability. Moreover, the ESTAR representation is evidence that sustainability is the result of active debt management rather than tax-smoothing. The results strongly support the active debt management hypothesis for the UK.

\section{Introduction}

During the last quarter of the $20^{\text {th }}$ century the pattern of public debt accumulation in many OECD countries made the sustainability of fiscal policy an issue of debate. Policy maker's concerns surfaced in the form of Gramm-RudmanHollings legislation in the US and the fiscal criteria in the Maastricht Treaty and its successor the Stability and Growth Pact. In the literature there were papers devoted to measuring the gap between existing policy and sustainable policy (Blanchard, 1990; Blanchard, Chouraqui, Hagemann and Sartor, 1990; Chouraqui, Hagemann and Sartor, 1990), papers assessing the distribution of debt and taxes between generations (Auerbach, Gokhale and Kotlikoff, 1992; 1993; 1994 and 1995), papers advocating present-value tests of the government intertemporal budget constraint (Hamilton and Flavin, 1986; Wilcox, 1989), papers focusing on alternative parameters from the government's intertemporal budget constraint (Trehan and Walsh, 1991; MacDonald, 1992), papers attempting to provide better empirical tests of the present-value approach (Kremmers, 1988; 1989) and, papers using present-value tests to examine the sustainability of various countries public finances (Corsetti and Roubini, 1991).

Testing the sustainability of fiscal policy using a present-value approach was pioneered by Hamilton and Flavin (1986). Hamilton and Flavin interpreted the present-value tests as indicative of whether the government was subject to an intertemporal constraint similar to households. An alternative interpretation was placed on present-value tests by Wilcox (1989) when he suggested that the government's intertemporal budget constraint must hold ex-post but that it may not hold ex-ante. The fact that the government is subject to an intertemporal budget constraint ex-post implies that the ratio of public debt to Gross Domestic Product 
(GDP) will be mean-reverting over longer horizons. Present-value tests that cannot reject the unit root are taken as evidence that current fiscal policy is unsustainable

While Wilcox's interpretation of the tests became the standard, the full implications of his interpretation are not always appreciated. Wilcox only suggested that the constraint must hold ex-post but he did not specify the manner in which this would be achieved by the fiscal authorities. Therefore, the appropriate test of fiscal policy sustainability should capture the possibility that the conduct of fiscal policy results in nonlinear movements in public debt. In particular, the conduct of fiscal policy might be such that policy interventions to ensure sustainability might only occur when sizable deviations from normal levels of public indebtedness occur. The acceptance of such a hypothesis has important theoritical implications because a nonlinear adjustment of this form is not consistent with the tax-smoothing hypothesis about the conduct of fiscal policy (Barro, 1979). Therefore, the presence of nonlinearity in the UK debt to GDP ratio can be taken as evidence that the UK did not follow a tax-smoothing policy for the period in question. This paper assesses whether the UK followed tax-smoothing policies between 1919 and 2001 using an ESTAR model to test for the presence of nonlinearity in the UK debt to GDP ratio.

The remainder of the paper is set out as follows. Section II motivates the choice of UK fiscal policy for the period since 1919, in addition to providing an overview of the philosophy of UK fiscal policy and public debt management for the period. Section III presents a simple test of the active debt management hypothesis against the alternative tax-smoothing hypothesis using the debt-GDP ratio and recently developed techniques in parametric nonlinear modelling. The procedure for selecting the appropriate modelling of the debt-GDP ratio is outlined in Section IV. The empirical results are presented in section V. Section VI concludes the study.

\section{UK Fiscal Policy and Post-World War I UK Debt Data}

The behaviour of the UK debt to GDP ratio during the $20^{\text {th }}$ century suggests that the UK engaged in a more active management of the debt than might be consistent with tax-smoothing. This behaviour is in contrast with UK behavior of the previous two centuries. It is, therefore, not surprising to find that the empirical paper that lends support to the tax-smoothing hypothesis using UK data covers only the 
period prior to 1919 (Barro, 1987). Another paper that supports the tax-smoothing hypothesis uses US data for the period 1919 - 1983 (Barro, 1986). It is therefore instructive to briefly examine the behaviour of UK debt since 1919 and to compare it with its behaviour prior to 1919 .

\section{Pre- World War I UK Debt}

Following a century and a half of intermittent war public debt in the UK debt rose from a low of $£ 2 \mathrm{~m}$ in 1688 immediately after the 'Glorious Revolution' to $£ 844.3 \mathrm{~m}$ by 1819 (Mitchell, 1988). It then declined slowly to $£ 774.9 \mathrm{~m}$ in 1835 before stabilising between $£ 780 \mathrm{~m}$ and $£ 790 \mathrm{~m}$ until it increased to $£ 812 \mathrm{~m}$ at the end of the Crimean War. It is, therefore, not surprising that Barro (1987) found that UK fiscal policy for the period 1700 to 1918 was consistent with tax-smoothing - public debt was used primarily to finance each war. However, it should be noted that income tax was used, even if only in a limited way, as a means of war finance in the UK (Barro (1987) also cites the use of debt management by the UK Treasury). Indeed, income tax was first introduced as a means of war finance "in 1799 after six years of improvident financing of the French War, [it] was allowed to lapse in 1802 with the Peace of Amiens, but was reintroduced in 1806 in a stronger form and was retained until after the victory in 1815 ... Peel in 1842 ... reintroduced Pitt's income tax" (Jenkins 1995:152). Peel introduced the tax on a three-year basis but it was extended for two further three-year periods and two one-year periods before Gladstone extended it for seven years in his 1853 budget.

Although there was a tendency in the UK to adjust taxes, if only partly, to pay for various wars, the capacity to do so was limited by a basic administrative structure for public finance. However, that started to change from the middle of the $19^{\text {th }}$ century. Gladstone's marshalling of the budgetary resources meant that he increased the potential of the budget as an instrument of policy. His centralisation of revenue and expenditure in the Consolidation Fund and the enforcement of uniformity in accounting methods and account presentation were the first two steps in this process (Hicks, 1958; Jenkins, 1995). Therefore, as the $19^{\text {th }}$ century progressed the potential for active management of the public finances increased but it was the $20^{\text {th }}$ century before it became the norm. 
The natural logarithm of UK public debt is presented in Figure 1 with the corresponding data for the US presented for comparison purposes. ${ }^{1}$ The smoother pattern of UK public debt accumulation prior to WWI is obvious. While military conflict played a substantial part in the dramatic pattern in the US debt, the largest single cause driving the US figures relates to the perception of public debt held by leading figures in US policy making after achieving independence from the UK. Beginning with positions taken by Federalists like Alexander Hamilton and antiFederalists like Thomas Jefferson, public debt was viewed as either a blessing or a burden. This was most dramatically illustrated in the middle of the $19^{\text {th }}$ century when Andrew Jackson was elected President on the promise to repay the public debt.

\section{Post-World War I UK Debt}

Figure 2 presents the UK debt to GDP ratio for the period 1919 to $2001 .^{2}$ The ratio is driven by economic conditions during the interwar period. There is a sharp rise in the ratio during WWII and an almost equally sharp decline in the post-WWII years. A relatively sharp decline continues up to the late 1960's when the ratio levels off.

In preparing his 1919 budget Austen Chamberlain was faced with a debt that was 10 times that he faced in 1905 during his first period in the Treasury. His 1919 and 1920 budget sought substantial increases in taxation in an effort to deal with the debt overhang from the war - the 1920 increase in taxation was the largest as a percentage in the $20^{\text {th }}$ century (Jenkins, 1998:137-8). It is accepted that a balancedbudget $^{3}$ philosophy dominated British budgets in the interwar period with Chancellors identify debt redemption as a high priority (Winch, 1983; Richardson, 1983; Jenkins, 1998). Debt redemption was the primary aim of Chamberlain's immediate successors Robert Horne and Stanley Baldwin (Jenkins, 1998:240 and 248). By the mid 1920's fiscal rectitude was being advocated as necessary to buttress the return of sterling to the Gold Standard. Whereas, during the Churchill budgets of the mid-to-late 1920's,

\footnotetext{
${ }^{1}$ US debt data is from Gordon (1998) and UK debt is from Mitchell (1988) and International Financial Statistics database of the International Monetary Fund

${ }^{2}$ The debt and Gross Domestic Product figures are taken from Feinstein (1976) and the International Financial Statistics database of the International Monetary Fund.

${ }^{3}$ Payments to a Sinking Fund for debt redemption were included in the budget arithmetic. This resulted in situations where the Chancellor was borrowing in order to pay into the Sinking Fund. This arrangement was introduced in 1875 and amended to a fixed $£ 40 \mathrm{~m}$ payment in the 1923 budget of Stanley Baldwin.
} 
the balanced-budget philosophy was justified by reference to Britian's return to the Gold Standard, the break with the standard was also used to justify fiscal rectitude in the budgets of Philip Snowden as a counter to inflationary pressures (Winch, 1983). In fact, Snowden stated that his primary role was the reduction of the national debt (Jenkins, 1998:278).

The 1941 budget is seen as the beginning of the Keynesian Era because it was the first time the budget was used as an instrument of wider government policy (Feinstein, 1983). Kingsley Wood's budget paved the way for the 1944 White Paper on Employment Policy and the greater "management” of the UK economy. The 1941 budget was heavily influenced by Keynes's monograph How to Pay for the War: A Radical Plan for the Chancellor of the Exchequer. ${ }^{4}$ The budget included a standard income tax rate of $50 \%$ with a marginal rate of $97.5 \%$, a small compulsory savings element with a partial repayment promised after the War. Keynes advocated that such a repayment be financed by a pre-announced capital levy. Hugh Dalton's two immediate post-WWII budgets similarly followed this redistributive approach when he increased surtax and death duties (Jenkins, 1998:449)

Keynes's monograph How to Pay for the War: A Radical Plan for the Chancellor of the Exchequer is not inconsistent with his counter-cyclical demand management proposals nor is it inconsistent with the view that Keynes introduced a bias toward deficit accumulation by advocating deficit financing of public expenditure during recessions (Buchanan and Wagner, 1977). The monograph is consistent with Keynes's advocacy of discretionary rather than non-tax smoothing policies. Cooley and Ohanian (1997) argue that this was a departure from tax-smoothing and show that the UK policy was in sharp contrast with the behaviour of the US authorities. Whereas the UK returned it debt-GDP ratio to it pre-war level by the mid-1950s, the US only returned to the ratio by the mid-1960s. ${ }^{5}$

In the decade and a half from 1951 Britain enjoyed good growth rates relative to its past performance (even if relatively poor by comparison with other countries

\footnotetext{
${ }^{4}$ Recent work has examined Keynes's advocacy of debt repayment in the immediate aftermath of WWII (Cooley and Ohanian, 1997; and Clarke, 1998).

${ }^{5}$ Barro (1986) finds US behaviour since WWI to be consistent with the tax-smoothing hypothesis. However, it should be noted that it is believed that the US authorities departed from tax smoothing to finance the Korean war (Ohanian, 1997).
} 
during this period). Budgetary issues assumed a lower priority during 1951-1967 because of Balance of Payments and Sterling difficulties. The improved growth performance helped reduce the debt to GDP ratio. The improvement in the ratio was halted with the problems caused by the international economic environment plus Britain's internal problems during the 1970's.

\section{Nonlinearity in the Debt-GDP Ratio}

While not stated explicitly in the literature, the linear specification can be justified using the tax-smoothing hypothesis about the conduct of fiscal policy (Barro, 1979). The tax-smoothing hypothesis suggests that fiscal authorities choose to smooth taxes to avoid the intertemporal distortions associated with changing tax rates. The optimal tax rate is chosen such that the government intertemporal budget constraint holds in the limit and the result is that temporary shocks to public expenditure map into changes in public debt, with permanent shocks resulting in a change in the tax rate and no change in public debt. Because the government budget intertemporal budget constraint is specified for an infinite horizon, once a temporary shocks such as wars has passed there should only be a very small change in any subsequent one period deficit, e.g. only a tiny surplus would be required to repay a 100 unit debt over 1,000 years. Moreover, the implications for all future deficits are the same and there should be no rush to repay the debt. These features of the taxsmoothing approach to fiscal policy have two implications for present-value tests of sustainability and their interpretation. First, the slow repayment of any debt might make the process indistinguishable for a unit root process. Second, there should be no attempt to return to some normal level of indebtedness in the short-run.

Linear models are likely to be too restrictive to adequately capture asymmetries that may exist in the debt-GDP ratio (Sarno, 2001). A parsimonious parametric time series model of nonlinear mean reversion which has been shown to approximate well a broad range of nonlinearity is the smooth transition autoregressive (STAR) model, as in Teräsvirta (1994). The exponential smooth transition autoregressive model of order q [ESTAR(q)] may be written:

(1) $\mathrm{y}_{\mathrm{t}}=\pi_{0}+\sum_{i=1}^{q} \pi_{\mathrm{i}} \mathrm{y}_{\mathrm{t}-\mathrm{i}}+\left[\pi_{0}^{*}+\sum_{i=1}^{q} \pi_{i}^{*} \mathrm{y}_{\mathrm{t}-\mathrm{i}}\right]\left[1-\exp \left\{-\gamma^{*}\left(\mathrm{y}_{\mathrm{t}-\mathrm{g}}-\mathrm{c}^{*}\right)^{2}\right\}\right]+\mathrm{u}_{\mathrm{t}}$ 
where $\mathrm{y}_{\mathrm{t}}$ is the debt-GDP ratio and is assumed stationary and ergodic, $\mathrm{u}_{\mathrm{t}}$ is a stochastic disturbance term, and $\gamma>0 .^{6}$ The exponential transition function $\mathrm{F}\left(\mathrm{y}_{\mathrm{t}-\mathrm{g}}\right)=1-\exp \left[-\gamma^{*}\left(\mathrm{y}_{\mathrm{t}-\mathrm{g}}-\mathrm{c}^{*}\right)^{2}\right]$ is U-shaped and bounded between zero and unity, with the (smoothness) parameter $\gamma^{*}$ determining the speed of the transition process between extreme regimes. The middle regime corresponds to $\mathrm{F}=0, \mathrm{y}_{\mathrm{t}-\mathrm{g}}=\mathrm{c}^{*}$, when (1) becomes a linear AR(q) model:

(2) $\mathrm{y}_{\mathrm{t}}=\pi_{0}+\sum_{i=1}^{q} \pi_{\mathrm{i}} \mathrm{y}_{\mathrm{t}-\mathrm{i}}+\mathrm{u}_{\mathrm{t}}$

The outer regime corresponds to the limit, $\lim \left|\mathrm{y}_{\mathrm{t}-\mathrm{g}}-\mathrm{c}^{*}\right| \rightarrow \infty$ when $\mathrm{F}=1$ and (1) becomes a different $\operatorname{AR}(q)$ model:

(3) $\mathrm{y}_{\mathrm{t}}=\left(\pi_{0}+\pi_{0}^{*}\right)+\sum_{i=1}^{q}\left(\pi_{\mathrm{i}}+\pi_{i}^{*}\right) \mathrm{y}_{\mathrm{t}-\mathrm{i}}+\mathrm{u}_{\mathrm{t}}$

Intermediate values of $\mathrm{F}$ will result in the dynamics governed by a linear combination of (2) and (3) with the weights given by (1-F) and F respectively. Global stability of the $\operatorname{ESTAR}(q)$ model requires

(4) $\sum_{i=1}^{q}\left(\pi_{i}+\pi_{i}^{*}\right)<1$.

Now, if

(5) $\sum_{i=1}^{q}\left(\pi_{\mathrm{i}}+\pi_{i}^{*}\right)<\sum_{i=1}^{q} \pi_{\mathrm{i}}$

then this would imply that the degree of mean reversion grows as the deviation from equilibrium grows, consistent with active management of public finances. On the other hand, if the reverse inequality holds, then the degree of mean reversion shrinks as the degree of disequilibrium grows, consistent with the tax-smoothing hypothesis. Thus, from (5), we can deduce that support for the active debt management hypothesis would be provided if the estimated value of $\sum_{i=1}^{q} \pi_{i}^{*}$ were negative and significantly different from zero, while support for the tax-smoothing hypothesis would be provided if this sum were positive and significantly different from zero.

\footnotetext{
${ }^{6}$ The ESTAR model can be viewed as a generalization of the exponential autoregressive (EAR) model with $\pi_{0}^{*}=\mathrm{c}^{*}=0$, or as a generalization of a special case of a double-threshold autoregressive (TAR) model, as in Teräsvirta (1994). However, for STAR models, regime changes occur gradually (smooth) rather than abruptly, as they do in TAR models. A smooth, rather than a discreet regime change is likely to be more realistic and appropriate when dealing with aggregated processes (Granger and Teräsvirta, 1993; Teräsvirta, 1994).
} 
For our purpose, it is worthwhile to reparameterise the ESTAR model in (1)

as:

$$
\text { (6) } \begin{aligned}
\Delta \mathrm{y}_{\mathrm{t}}=\pi_{0}+\lambda \mathrm{y}_{\mathrm{t}-1} & +\sum_{i=1}^{q-1} \delta_{\mathrm{i}} \Delta \mathrm{y}_{\mathrm{t}-\mathrm{i}} \\
& +\left[\pi_{0}^{*}+\lambda^{*} \mathrm{y}_{\mathrm{t}-1}+\sum_{i=1}^{q-1} \pi_{i}^{*} \Delta \mathrm{y}_{\mathrm{t}-\mathrm{i}}\right]\left[1-\exp \left\{-\gamma^{*}\left(\mathrm{y}_{\mathrm{t}-\mathrm{g}}-\mathrm{c}^{*}\right)^{2}\right\}\right]+\mathrm{u}_{\mathrm{t}}
\end{aligned}
$$

In this form the crucial parameters are $\lambda$ and $\lambda^{*}$. For global stability we require $\left(\lambda+\lambda^{*}\right)<0$. However, if it is the case that the larger the deviation from the long-run equilibrium, the stronger is the tendency to move back to fundamental equilibrium, then we must have $\lambda^{*}<0$ and $\left(\lambda+\lambda^{*}\right)<0$, while $\lambda \geq 0$ is possible. That is, for small deviations $y_{t}$ may follow a unit root or even explosive behaviour, but for large deviations the process is mean reverting.

As pointed out by Granger and Teräsvirta (1993), representing the ESTAR model in the form of (6) allows us to compare it with the linear augmented DickeyFuller ADF(q) regression: $\Delta \mathrm{y}_{\mathrm{t}}=\pi_{0}+\lambda \mathrm{y}_{\mathrm{t}-1}+\sum_{i=1}^{q-1} \delta_{\mathrm{i}} \Delta \mathrm{y}_{\mathrm{t}-\mathrm{i}}+\mathrm{u}_{\mathrm{t}}$, where the unit root hypothesis $\mathrm{H}_{0}: \lambda=0$. However, if $\left(\lambda+\lambda^{*}\right)<0$ and $\lambda^{*}<0$, indicating that $\mathrm{y}_{\mathrm{t}}$ is a nonlinear stationary process we still might find that $\lambda=0$. That is, if $y_{\mathrm{t}}$ is best described as an ESTAR process, failure to reject the unit root hypothesis using a standard linear ADF does not necessarily imply that $\mathrm{y}_{\mathrm{t}}$ is not mean reverting.

\section{Linearity testing and model selection}

Teräsvirta (1994) suggest testing linearity against ESTAR by first specifying the appropriate order of the autoregressive components, q, and suggests choosing this from an examination of the partial autocorrelation function (PACF) of $y_{t}$ in the usual fashion. For a given value of the delay parameter g, Granger and Teräsvirta (1993) and Teräsvirta (1994) show that appropriate tests of the null hypothesis of linearity against an alternative hypothesis of nonlinear adjustment may be based on the artificial regression:

(7) $\mathrm{y}_{\mathrm{t}}=\beta_{00}+\sum_{i=1}^{q}\left(\beta_{1 \mathrm{i}} \mathrm{y}_{\mathrm{t}-\mathrm{i}}+\beta_{2 \mathrm{i}} \mathrm{y}_{\mathrm{t}-\mathrm{i}} \mathrm{y}_{\mathrm{t}-\mathrm{g}}+\beta_{3 \mathrm{i}} \mathrm{y}_{\mathrm{t}-\mathrm{i}} \mathrm{y}_{t-g}^{2}+\beta_{4 \mathrm{i}} \mathrm{y}_{\mathrm{t}-\mathrm{i}} \mathrm{y}_{t-g}^{3}\right)+\varepsilon_{\mathrm{t}}$. 
Since (7) may be viewed as a reparameterization of (1), with an unrestricted thirdorder Taylor series expansion of the transition function, an appropriate simple test of nonlinearity is clearly an F-test, $F_{1}$, of the following restrictions on (7):

(8) $\mathrm{H}_{01}: \beta_{2 \mathrm{i}}=\beta_{3 \mathrm{i}}=\beta_{4 \mathrm{i}}=0, \quad \mathrm{i}=1, \ldots, \mathrm{q}$

against the alternative that $\mathrm{H}_{01}$ is not valid.

If the transition function is of the exponential family discussed above, however, third-order terms vanish in its Taylor series expansion, see Granger and Teräsvirta (1993). Intuitively, because the exponential transition function is U-shaped as a function of $\mathrm{y}_{\mathrm{t}-\mathrm{g}}$, it will be better approximated by a quadratic than by a cubic. If the debt-GDP ratio averaged over the whole sample period has been close to the equilibrium level, we would also expect the ESTAR model (1) to satisfy $\pi_{0}^{*}=\mathrm{c}^{*}=0$, this further implies $\beta_{2 \mathrm{i}}=0$ in (7). This reasoning therefore suggests the following sequence of tests:

(9a) $\mathrm{H}_{04}: \beta_{4 \mathrm{i}}=0, \quad \mathrm{i}=1, \ldots, \mathrm{q}$

(9b) $\mathrm{H}_{03}: \beta_{3 \mathrm{i}}=0 \mid \beta_{4 \mathrm{i}}=0, \quad \mathrm{i}=1, \ldots, \mathrm{q}$

(9c) $\mathrm{H}_{02}: \beta_{2 \mathrm{i}}=0 \mid \beta_{4 \mathrm{i}}=0, \quad \mathrm{i}=1, \ldots, \mathrm{q}$

where we might denote the relevant Wald-statistics for (9a), (9b) and (9c) respectively by $\mathrm{W}_{4}, \mathrm{~W}_{3}$ and $\mathrm{W}_{2}$. If the true model is ESTAR, we would expect not to reject $\mathrm{H}_{04}$ but to reject $\mathrm{H}_{03}$, and if in addition the sample mean value of $\mathrm{y}_{\mathrm{t}}$ is close to the equilibrium value, we would expect not to reject $\mathrm{H}_{02}$.

Of course, in practice $\mathrm{g}$ is not known. We therefore follow the procedure suggested by Granger and Teräsvirta (1993) and Teräsvirta (1994) for selecting g. This involves testing the null hypothesis $\mathrm{H}_{01}$ for a range of values of $\mathrm{g}=1,2, \ldots \mathrm{G}$, and in each case calculating the Wald-statistic $\mathrm{W}_{1}(\mathrm{~g})$. The delay parameter $\hat{\mathrm{g}}$ is then chosen such that $\mathrm{W}_{1}(\hat{\mathrm{g}})=\sup _{\mathrm{g}} \mathrm{W}_{1}(\mathrm{~g}), \mathrm{g}=1, \ldots ., \mathrm{G}$. Although it might be thought that maximizing the test statistic in this fashion would generate substantial pre-test bias, the Monte Carlo evidence of Teräsvirta (1994) suggests that this should only lead to slight bias in the test size. If this procedure leads to linearity being rejected in favor of an ESTAR(q) model, we follow Tong (1990) in estimating (6) by nonlinear least squares, which provides estimators that are consistent and asymptotically normally distributed. We use heteroskedasticity-robust forms of these Wald statistics in our empirical work (see White, 1980). 


\section{Empirical Results}

The UK debt and GDP data for the period 1919 to 1960 are taken from Feinstein (1976) and for the period 1961 to 2001 comes from the IMF's International Financial Statistics.

The distribution properties of the UK debt-GDP ratio reveal some degree of persistence in the ratio and it tends to die away slowly. The first-order autocorrelation values are close to one suggesting that the ratio is non-stationary. Furthermore, when we reparameterize the standard linear AR(2) $\operatorname{model}^{7}$ as an augmented Dickey-Fuller (ADF) regression, we find that for the UK debt-GDP ratio:

$$
\begin{aligned}
& \Delta \mathrm{y}_{\mathrm{t}}=\begin{array}{cc}
0.014-0.017 \mathrm{y}_{\mathrm{t}-1} & +0.628 \Delta \mathrm{y}_{\mathrm{t}-1} \\
(0.018) \quad(0.014) \quad & (0.086) \\
{[0.796][-1.267] \quad[7.334]} &
\end{array} \\
& \bar{R}^{2}=0.39 \quad \mathrm{SSE}=0.42 \quad \mathrm{Q}=0.20
\end{aligned}
$$

where, $\mathrm{y}_{\mathrm{t}}$ is the debt-GDP ratio; $\Delta$ is the first-difference operator; the figures in parentheses are standard errors and t-ratios are given in brackets. $\bar{R}^{2}$ is the adjusted coefficient of determination; SSE is the sum of squared residuals; and Q denotes the marginal significance level for the Ljung-Box Q statistic test for serial correlation of the residual term.

These basic results indicate that standard ADF would accept the null hypothesis that the debt-GDP ratio is non-stationary. However, as we outlined in section III, this does not necessarily imply that the debt-GDP ratio is not mean reverting. If the true process for the debt-GDP ratio is nonlinear (of a form given by (6)) then even though $\lambda=0$ (as above), with a $\lambda^{*}$ large and significantly negative, the larger the deviation of the debt-GDP ratio from its equilibrium, the stronger is the tendency for it to move back to its equilibrium level. That is, for small deviations the debt-GDP ratio may follow a unit root or even explosive behaviour, but for large deviations the process is mean reverting.

\footnotetext{
${ }^{7}$ The choice of a lag order $\mathrm{q}=2$ is indicated by the partial autocorrelation function (PACF), see Figure 3. Furthermore, Granger and Teräsvirta (1993) suggests that the PACF approach is more appropriate than some information criteria, e.g., the Akaike Information Criterion (AIC), because (i) the information criteria could be misleading when the true process is nonlinear, and (ii) unlike the information criteria selection processes, the PACF imposes no penalty on a higher order AR, when it may be the case that high-order AR models could provide reasonable approximations to a nonlinear model.
} 
Examination of the PACF of the debt-GDP ratio $y_{t}$ (see Figure 3) reveals significant correlations up to order two. Accordingly the linearity tests are based on the artificial regression (7) with q set equal to two. Table 1, which reports tests of linearity, provides strong evidence of nonlinearity: $\mathrm{W}_{1}$ rejects linearity at the near zero percent level for $\mathrm{g}=3$ and the $\mathrm{W}_{4}, \mathrm{~W}_{3}$, and $\mathrm{W}_{2}$ statistics strongly suggest that an $\operatorname{ESTAR}(2)$ model with $\mathrm{g}=3$ and $\pi_{0}^{*} \neq 0$ and/or $\mathrm{c}^{*} \neq 0$ is the most appropriate parameterization for $\mathrm{y}_{\mathrm{t}}$. In estimating the nonlinear model we follow Teräsvirta (1994) and standardize the exponent of the transition function $\mathrm{F}$ by dividing it by $\sigma_{y}^{2}$ the sample variance of $y_{t}$, and choosing a starting value for the standardized smoothness parameter equal to 1 .

Table 1: p-Values for the Linearity Tests of the Debt-GDP Ratio, $\mathrm{y}_{\mathrm{t}}$ : AR(2)

\begin{tabular}{lcccc}
\hline \hline & $\mathrm{W}_{1}$ & $\mathrm{~W}_{4}$ & $\mathrm{~W}_{3}$ & $\mathrm{~W}_{2}$ \\
\hline $\mathrm{g}=1$ & 0.0180 & 0.2254 & 0.0697 & 0.0287 \\
$\mathrm{~g}=2$ & 0.0039 & 0.1615 & 0.0304 & 0.0132 \\
$\mathrm{~g}=3$ & 0.0005 & 0.1336 & 0.0011 & 0.0392 \\
$\mathrm{~g}=4$ & 0.0015 & 0.0494 & 0.0017 & 0.2782 \\
$\mathrm{~g}=5$ & 0.0492 & 0.3827 & 0.0067 & 0.7136 \\
$\mathrm{~g}=6$ & 0.3688 & 0.4800 & 0.1705 & 0.4716 \\
$\mathrm{~g}=7$ & 0.4227 & 0.5186 & 0.4500 & 0.2079 \\
$\mathrm{~g}=8$ & 0.0882 & 0.2205 & 0.1090 & 0.1681 \\
\hline \hline
\end{tabular}

Notes: The sample period is 1919-2001. The artificial regression (7), used to calculate the linearity Wald-tests, are based on q set equal to two. All test statistics were constructed using heteroskedasticity-robust methods (see White, 1980).

The estimated parsimonious nonlinear model is the ESTAR(2) model:

$$
\begin{aligned}
& \Delta \mathrm{y}_{\mathrm{t}}=0.040+1.239 \Delta \mathrm{y}_{\mathrm{t}-1}+\left[-0.083 \mathrm{y}_{\mathrm{t}-1}-0.606 \Delta \mathrm{y}_{\mathrm{t}-1}\right] \\
& \begin{array}{llll}
(0.014) & (0.193) & (0.016) & (0.213)
\end{array} \\
& {[2.824] \quad[6.429] \quad[-5.079] \quad[-2.842]} \\
& \times\left[1-\exp \left\{-\left(6.003 / \sigma_{y}^{2}\right)\left(\mathrm{y}_{\mathrm{t}-3}-1.455\right)^{2}\right\}\right] \\
& \text { (2.745) (0.025) } \\
& \text { [2.187] [57.410] } \\
& \bar{R}^{2}=0.55 \\
& \sigma_{y}^{2}=0.36 \\
& \mathrm{SSE}=0.30 \\
& \operatorname{LR}(2)=2.69\{0.07\} \\
& \operatorname{ARR}(2)=0.34\{0.72\} \\
& \mathrm{VR}=0.70
\end{aligned}
$$


The figures in parentheses are standard errors and t-ratios are given in brackets. For the LM and LR tests, marginal significance levels are given in braces. $\bar{R}^{2}$ is the adjusted coefficient of determination; ARR(2) denotes a Lagrange multiplier test statistics for up to second-order autocorrelation of the residuals, as in Eitrheim and Teräsvirta (1996); VR is the ratio of the residual variance from the estimated ESTAR model to the residual variance from the estimated best fitting alternative linear model (that is an $\mathrm{AR}(2)$ ); and $\sigma_{y}^{2}$ is the sample variance of the debt-GDP ratio. The likelihood ratio statistic LR(2) tests the two parsimonious parameter restrictions implicit in the estimated model against the unrestricted ESTAR(2) model - described by equation (6). The estimated LR test statistic suggests that the restrictions hold at the 5 per cent significance level.

The estimated model clearly fits well, with well determined coefficients and satisfactory diagnostics. Moreover, the model reports a 30\% reduction in the residual variance from the estimated ESTAR model compared to the linear regression (10).

The scatter plot of the estimated transition function against $\left(\mathrm{y}_{\mathrm{t}-3}-1.455\right)$ given in Figure 4, shows that the distribution of the debt-GDP ratio is in fact more or less symmetrically distributed around the estimated mean. With a simple count showing slightly more than $50 \%$ of the deviations are below the mean. Moreover, the pattern of the scatter plot is symmetric illustrating that the active management occurred when the ratio was substantially away from it equilibrium, either above or below. This suggests that there was indeed a 'Keynesian' revolution in the UK. It is interesting to compare the scatter plot for the UK with that for the US in Sarno (2001). In the US the distribution is also symmetric in that there is approximately $50 \%$ above and below the mean. However, the more extreme values in the scatter plot occur when the ratio is above its equilibrium.

It is also apparent from Figure 4 that for large deviations from the ratio's longrun level there is some evidence of a very fast adjustment back towards its long-run level. This impression is confirmed formally, with the unstandardized value of the (smoothness) parameter $\gamma^{*}$ of about 16.76, suggesting a fast adjustment. More importantly, a large number of observations lie in the outer regime $(\mathrm{F}=1)$ confirming the presence of strong nonlinearities properties of the debt-GDP ratio and with significant outer regime coefficients, the degree of mean reversion increases significantly with the size of the deviation of the debt-GDP ratio from its equilibrium. 
Furthermore, from the empirical results presented in (11) when $\mathrm{F}=0$ (middle regime) $\mathrm{y}_{\mathrm{t}}$ is a unit root process, but when $\mathrm{F}=1$, the significant coefficient value of -0.083 on the $\mathrm{y}_{\mathrm{t}-1}$ variable implies that $\mathrm{y}_{\mathrm{t}}$ is mean reverting and not a unit root. Thus, UK debtGDP is a nonlinear mean-reverting process.

The findings supports the hypothesis that governments react more strongly to deficits (and surpluses) when the deviation of the debt-GDP ratio from its equilibrium is large in absolute size and, therefore, the larger the deviation the stronger will be the tendency to move back to its equilibrium level. Thus, for the UK, the results support the active debt management hypothesis as opposed to the tax-smoothing hypothesis.

\section{Conclusion}

The UK debt-GDP ratio is a nonlinear process with well determined coefficients, satisfactory diagnostics and a $30 \%$ reduction in the residual variance from the estimated ESTAR model compared to the linear regression. The empirical results presented demonstrate that debt-GDP is a unit root process close to the equilibrium (middle regime), but it is mean reverting in the outer regime. Thus, UK debt-GDP is a nonlinear mean-reverting process. A large number of observations lie in the outer regime confirming the presence of strong nonlinearities properties of the debt-GDP ratio with mean reversion increasing significantly with the size of the deviation from equilibrium.

The ESTAR model allows us to discriminate between the active debt management hypothesis and the tax-smoothing hypothesis. The findings strongly support the active debt management hypothesis.

\section{References}

Auerbach, A.J., J. Gokhale and L.J. Kotlikoff (1992). "Generational Accounting: A New Approach to Understanding the Effects of Fiscal Policy on Saving”. Scandinavian Journal of Economics. 94, 303-318.

Auerbach, A.J., J. Gokhale and L.J. Kotlikoff (1993). "Generational Accounts and Lifetime Tax Rates, 1900-1991”. Economic Review. 29, 2-13. 
Auerbach, A.J., J. Gokhale and L.J. Kotlikoff (1994). "Generational Accounting: A Meaningful Way to Evaluate Fiscal Policy". Journal of Economic Perspectives. 8(1), Winter, 73-94.

Auerbach, A.J, J. Gokhale and L.J. Kotlikoff (1995). "Restoring Generational Balance in US Fiscal Policy : What Will It Take?". Federal Reserve Bank of Cleveland Quarterly Review.

Barro, R. J. (1979) “On the Determination of Public Debt.” Journal of Political Economy, vol. 87, October, pp 940-71.

Barro, R.J. (1986). “U.S. Deficits Since World War I.” Scandanavian Journal of Economics, 88(1), 195-222.

Barro, R. J. (1987) "Government Spending, Interest Rates, Prices and Budget Deficits in the United Kingdom, 1701-1918." Journal of Monetary Economics, Vol. 20, September, pp 221-47.

Blanchard, O.J. (1990). "Suggestions for a New Set of Fiscal Indicators". OECD Economic and Statistics Department, Working Papers No 79.

Blanchard, O.J., J. Chourqui, R.P. Hagemann and N. Sartor (1990). "The Sustainability of Fiscal Policy: New Answers to an Old Question". OECD Economic Studies No. 15.

Buchanan, J. M., and R. E. Wagner. (1977) Democracy in Deficit: the political legacy of Lord Keynes. Academic Press. Harcourt Brace Jovanovich, New York

Chouraqui, J.C., Hagemann, R.P. and N. Sartor (1990). "Indicators of Fiscal Policy: A Reassesment". OECD Working Papers No. 78.

Clarke, P. (1998) "Keynes, Buchanan and the balanced-budget doctrine." In John Moloney (editor) Debt and Deficits. Cheltenham, U.K.: Edward Elgar.

Cooley, T. F., and L. E. Ohanian. (1997) "Postwar British Economic Growth and the Legacy of Keynes.” Journal of Political Economy, vol. 105, no. 3, pp 439-72.

Corsetti, G and N. Roubini (1991). "Fiscal Deficits, Public Debt and Government Solvency: Evidence from OECD Countries". NBER W.P. No 3658.

Eitrheim, Ø., and T. Teräsvirta. (1996) “Testing the Adequacy of Smooth Transition Autoregressive Models." Journal of Econometrics, vol. 74, no. 1, pp. 59-75.

Feinstein, C.H. (1976). Statistical Tables of National Income, Expenditure and Output of the U.K. 1855-1965. Cambridge University Press, London.

Feinstein, C.H. (1983). The Managed Economy: Essays in British Economic Policy and Performance since 1929. Oxford University Press, New York.

Granger, C. J., and T. Teräsvirta. (1993) Modelling Nonlinear Economic Relationships. Oxford, U.K.: Oxford University Press. 
Hamilton, J. D., and M. A. Flavin. (1986) "On the Limitations of Government Borrowing: A Framework for Empirical Testing." American Economic Review, vol. 74, no. 4, pp 808-19.

Hicks, U. K. (1958) British Public Finances 1880-1952. Oxford, U.K.: Oxford University Press.

Jenkins, R. (1995) Gladstone. London, U.K.: Macmillan.

Jenkins, R. (1998). The Chancellors. London, U.K.: MacMillan.

Kremmers, J.J.M. (1988). 'Long-Run Limits on US Federal Debt'. Economic Letters. 28(3), 259-262.

Kremmers, J.J.M. (1989). 'US Federal Indebtness and the Conduct of Fiscal Policy'. Journal of Monetary Economics. 23(2), 219-238.

MacDonald, R. (1992). 'Some tests of the government's intertemporal budget constraint using US data'. Applied Economics. 24, 1287-1292.

Mitchell, B. R. (1988) British Historical Statistics. Cambridge, U.K.: Cambridge University Press.

Ohanian, L. E. (1997) "The Macroeconomic Effects of War Finance in the United States: World War II and the Korean War.” American Economic Review, vol. 87, no. 1 , pp 23-40.

Richardson, H.W. (1983). "Fiscal Policy in the 1930's" in C. H. Feinstein, (editor). The Managed Economy: Essays in British Economic Policy and Performance since 1929. Oxford University Press, New York.

Sarno, L. (2001) "The Behavior of US Public Debt: A Nonlinear Perspective." Economics Letters, vol. 74, no. 1, pp. 119-25.

Steele Gordon, John (1998). Hamilton’s Blessing. Penguin Book’s Ltd., England.

Teräsvirta, T. (1994) "Specification, Estimation, and Evaluation of Smooth Transition Autoregressive Models." Journal of the American Statistical Association, vol. 89 , no. 425 , pp. $208-18$.

Tong, H. (1990) Non-Linear Time Series: A Dynamical System Approach. Oxford, U.K.: Oxford University Press.

Trehan, B. and C. Walsh (1991). 'Testing Intertemporal Budget Constraints: Theory and Applications to US Fedral Budget and Current Account Deficits'. Journal of Money, Credit and Banking. 23(2), 206-223.

White, H. (1980) "A Heteroskedasticity-Consistent Covariance Matrix Estimator and a Direct Test for Heteroskedasticity.” Econometrica, vol. 48, pp. 817-38. 
Wilcox, D. W. (1989) "The Sustainability of Government Deficits: Implications of the Present Value Borrowing Constraint." Journal of Money, Credit and Banking, vol. 21, no. 3, pp 291-306.

Winch, D. (1983). "Britain in the 'Thirties: A Managed Economy?" in C. H. Feinstein, (editor). The Managed Economy: Essays in British Economic Policy and Performance since 1929. Oxford University Press, New York. 
Figure 1: Log UK and US Debt, 1691-1997

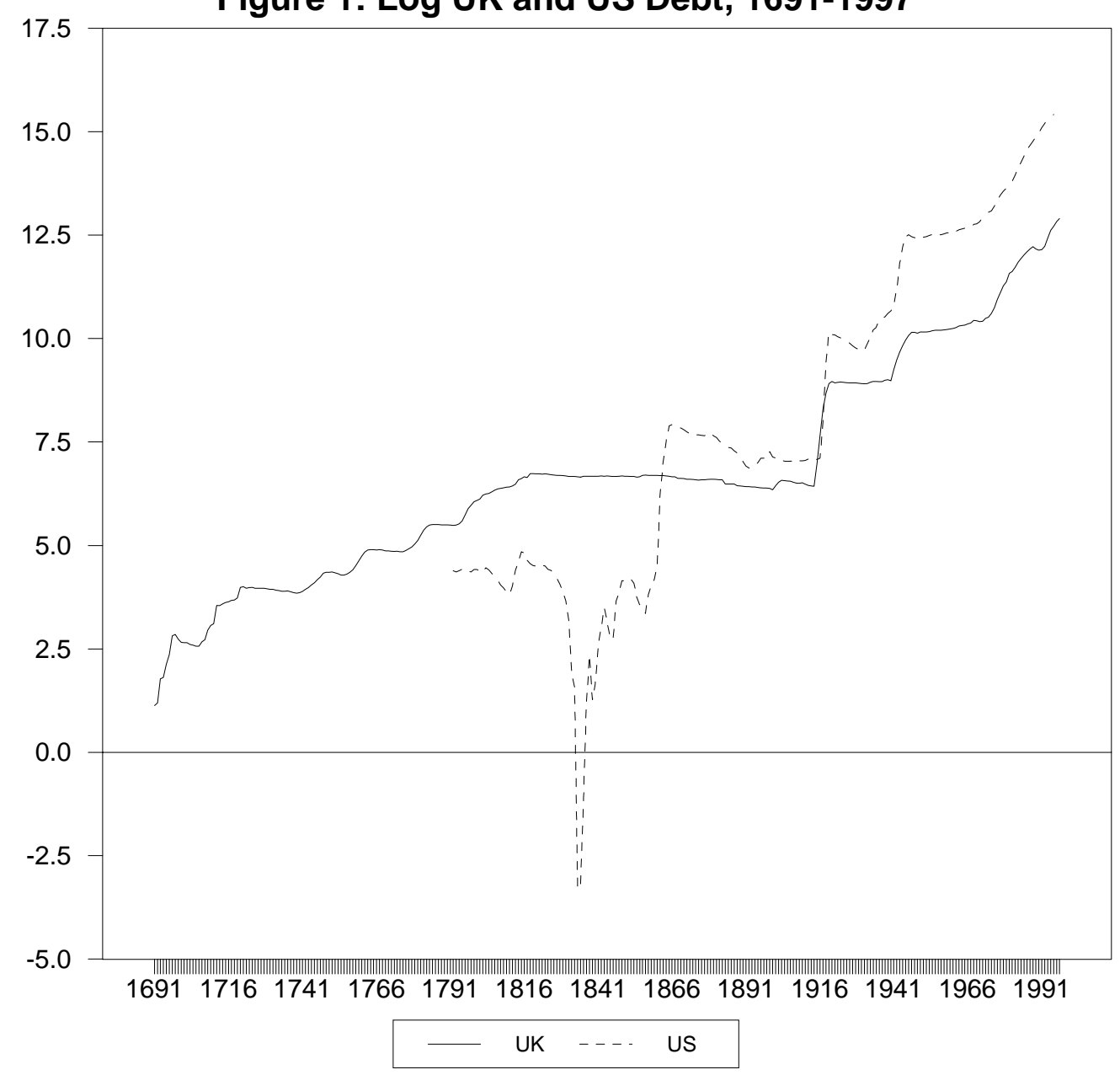


Figure 2: UK Debt-GDP Ratio, 1919-2001

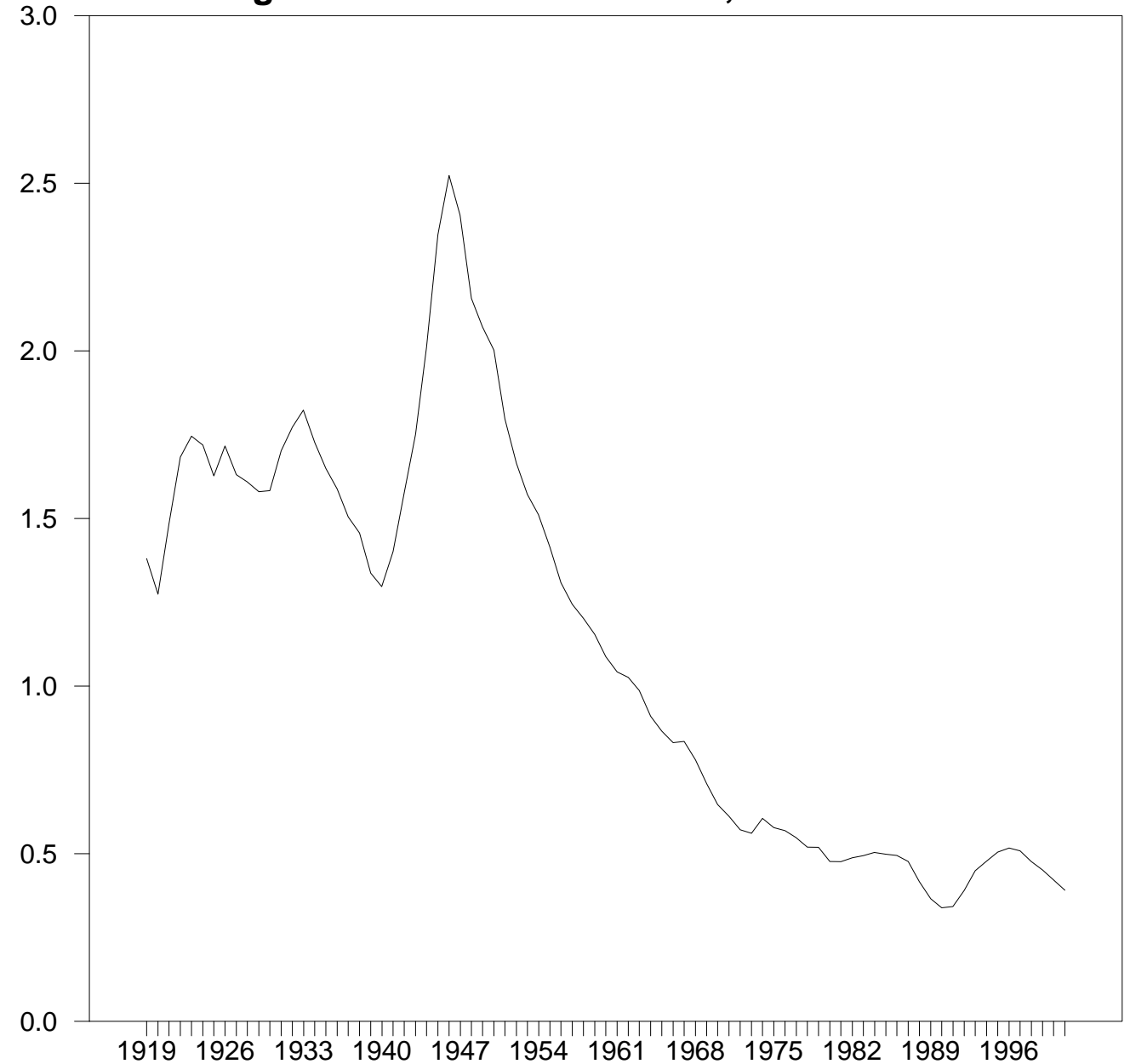


Figure 3: Partial Autocorrelation function

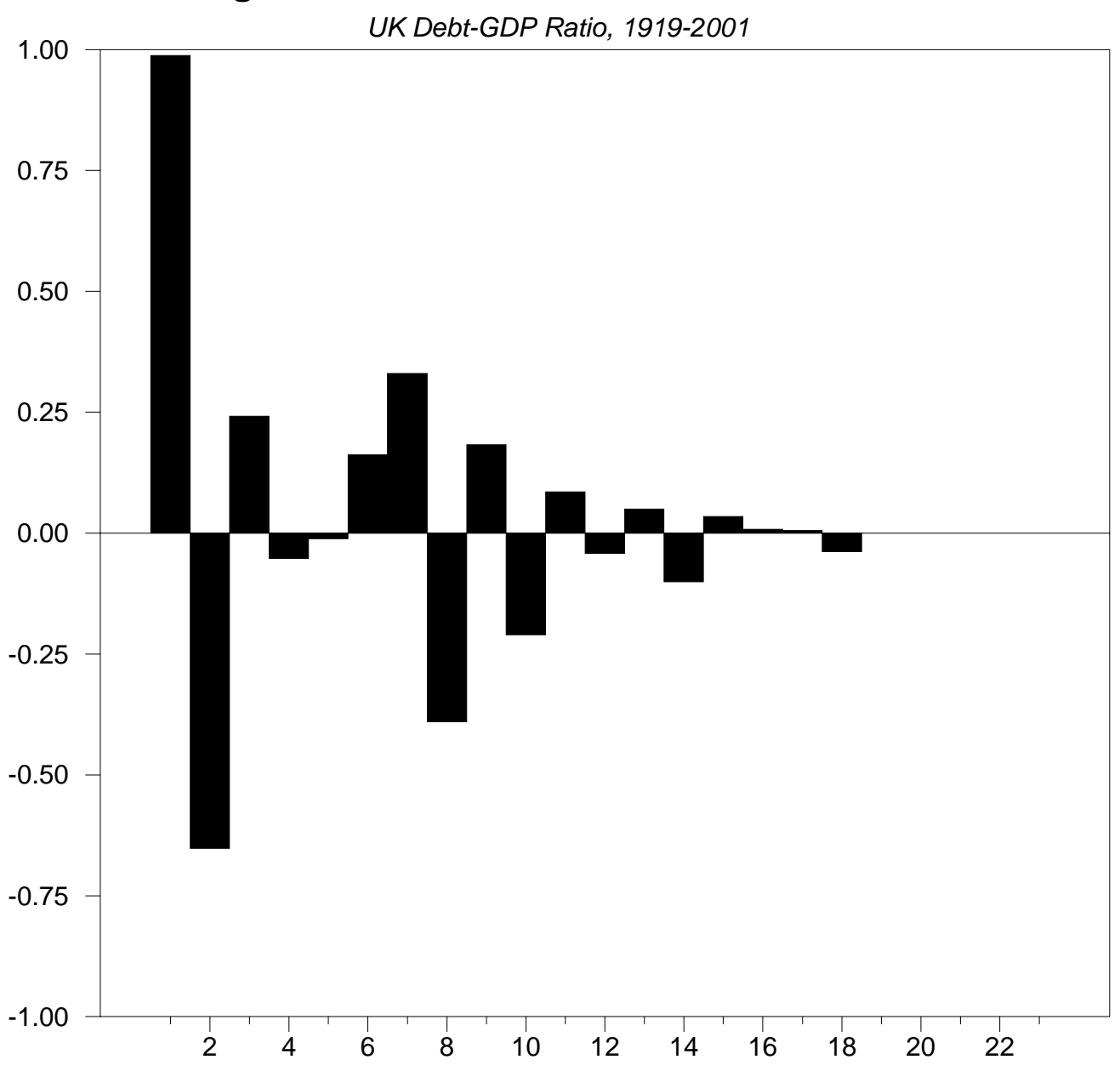


Figure 4: Estimated Transition Function

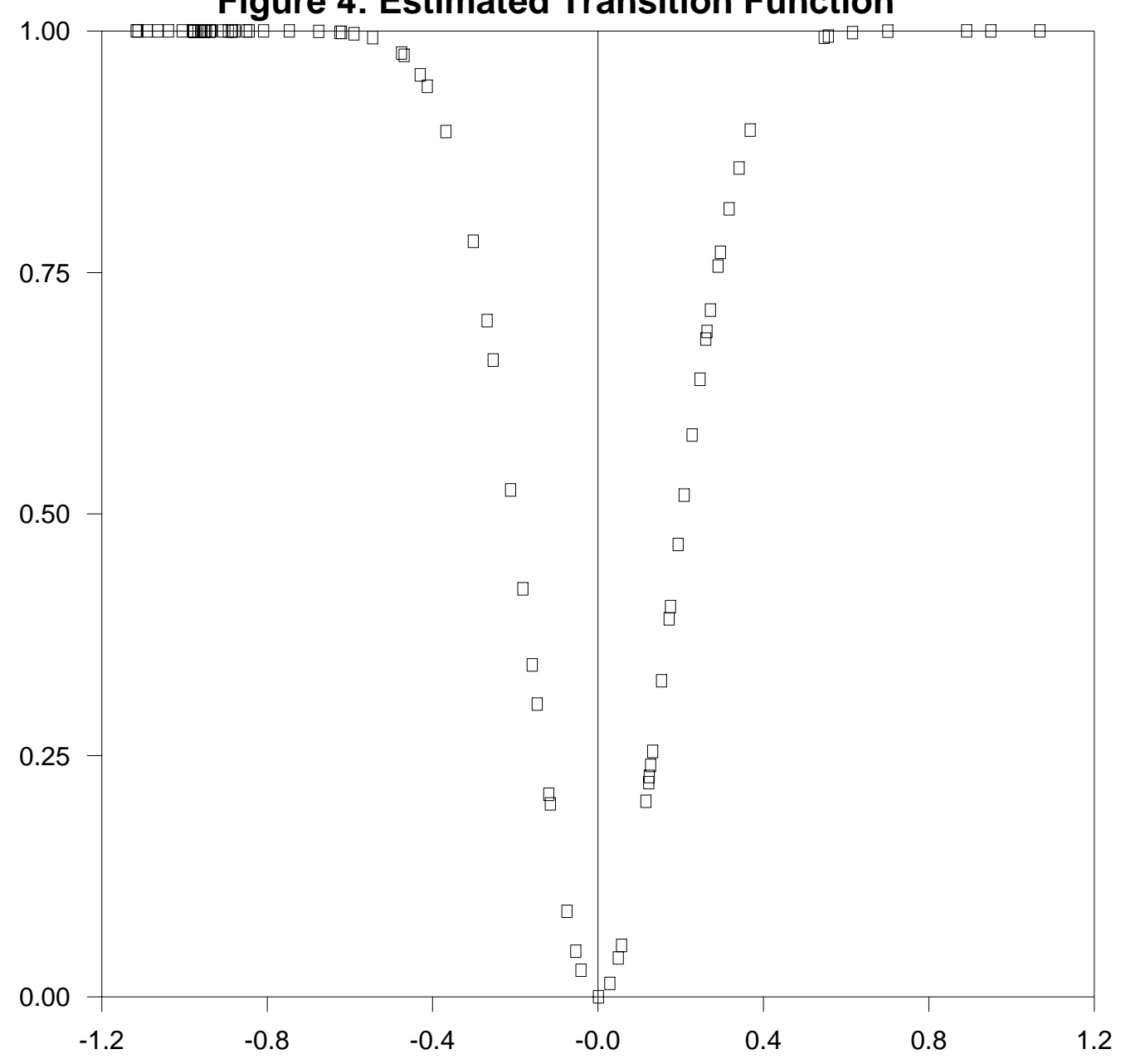

